TOMASZ RACHWAL

Uniwersytet Pedagogiczny w Krakowie, Polska - Pedagogical University of Cracow, Poland

KRZYSZTOF WACH

Uniwersytet Ekonomiczny w Krakowie, Polska - Cracow University of Economics, Poland

\title{
Badanie intencji przedsiębiorczych młodego pokolenia: wyniki ankietyzacji wśród studentów kierunków nieekonomicznych
}

\author{
An Investigation into Entrepreneurial Intensions of the Young Generation: Survey \\ Results Among Students of Non-economic Fields of Studies
}

\begin{abstract}
Streszczenie: Przedsiębiorczość zaliczana jest do jednych z podstawowych czynników podnoszenia konkurencyjności przedsiębiorstw i rozwoju społeczno-gospodarczego układów przestrzennych. Z tego punktu widzenia istotne jest kształtowanie postaw przedsiębiorczych młodych ludzi w procesie edukacyjnym i różnych formach kształcenia pozaszkolnego oraz rozpoznanie poziomu ich intencji przedsiębiorczych związanych z planowaniem założenia i prowadzenia własnego biznesu. Celem artykułu jest próba określenia wpływu wybranych czynników na intencje przedsiębiorcze młodzieży na podstawie wyników badań ankietowych przeprowadzonych wśród studentów kierunków nieekonomicznych przy wykorzystaniu teorii planowanego zachowania (theory of planned behaviour - TPB). Analiza wyników badań pozwoliła na weryfikację postawionych hipotez, czyli stwierdzenie m.in. prawidłowości, że wraz z pozytywnym wzrostem indywidualnej postawy względem prywatnej przedsiębiorczości i przedsiębiorców czy wzrostem poczucia własnej skuteczności przedsiębiorczej, zwiększają się intencje przedsiębiorcze badanych studentów. Podobnie na wzrost ten mają wpływ doświadczenia przedsiębiorczości rodzinnej. W konkluzjach wskazano na ograniczenia wnioskowania na podstawie przeprowadzonych badań empirycznych oraz możliwości rozszerzenia badań o nowe wątki badawcze.
\end{abstract}

\begin{abstract}
Entrepreneurship is considered one of the main factors improving competitiveness of firms and socio-economic development of spatial systems. From that point of view it is important to develop the entrepreneurial attitudes of young people within the education process as well as various forms of lifelong learning outside the classroom and to identify their level of entrepreneurial intentions related to the plans of setting up and running their own businesses. The purpose of this article is to determine the influence of some factors on entrepreneurial intentions of young people based on the results of surveys among students of non-economic fields of studies, using the theory of planned behaviour (TPB). The analysis of results allows for verification of the hypotheses, and to confirm, inter alia, some regularities, that the higher the positive individual attitude towards private entrepreneurship and entrepreneurs, as well as the higher the entrepreneurial self-efficacy, the higher entrepreneurial intentions of surveyed students. Similarly, this increase is affected by the experience of family entrepreneurship. In conclusions the limitations of reasoning based on empirical research and the possibility of extending the research of new topics are mentioned.
\end{abstract}


Słowa kluczowe: edukacja dla przedsiębiorczości; intencje przedsiębiorcze; przedsiębiorczość; studia wyższe; teoria planowanego zachowania

Key words: entrepreneurial intention (EI); entrepreneurship; entrepreneurship education (EE); higher education; theory of planned behaviour (TPB)

Otrzymano: 14 grudnia 2015

Received: 14 December 2015

Zaakceptowano: 11 kwietnia 2016

Accepted: 11 April 2016

\section{Sugerowana cytacja/Suggested citation:}

Rachwał, T., Wach, K. (2016). Badanie intencji przedsiębiorczych młodego pokolenia: wyniki ankietyzacji wśród studentów kierunków nieekonomicznych. Przedsiębiorczość - Edukacja, 12, 405-415.

\section{Wstęp}

Powszechnie przyjmuje się, że przedsiębiorczość jest jednym z ważnych czynników wpływających na procesy rozwoju społeczno-gospodarczego układów przestrzennych (krajowych, regionalnych i lokalnych) oraz kształtujących konkurencyjność przedsiębiorstw. Jak wskazuje wielu autorów (por. Daszkiewicz, 2013; Gaweł, 2011; Gubik, 2015; Pietrzykowski, 2011; Rachwał, 2010; Rachwał, Kurek, Boguś, 2016; Urbaniec, 2014; Wach, 2007, 2013, 2014a; Zioło, 2013), jednym z podstawowych warunków jej rozwoju jest odpowiedni proces edukacyjny, realizowany na wszystkich poziomach kształcenia, w tym także na poziomie szkoły wyższej (Sułkowski, 2016), którego celem powinno być przede wszystkim kształtowanie postaw przedsiębiorczych wśród młodzieży oraz studentów, warunkujących ich pełne i satysfakcjonujące uczestnictwo w życiu społeczno-gospodarczym (Marona, Głuszak, 2014; Piróg, 2015). Dlatego też przedsiębiorczość zaliczana jest do tzw. kompetencji kluczowych w europejskim systemie edukacyjnym, a wprowadzanie edukacji dla przedsiębiorczości na wszystkich szczeblach edukacji zajmuje znaczące miejsce w polityce Unii Europejskiej, szczególnie od początku XXI w. (Wach, 2014b; por. Najda-Janoszka, Wach, 2008). W szkolnictwie dotyczy to nie tylko zajęć $\mathrm{z}$ zakresu przedsiębiorczości, ale także innych przedmiotów szkolnych (Borowiec, Rachwał, 2011), a w kształceniu uniwersyteckim nie tylko studiów związanych z naukami ekonomicznymi, ale również, a może - przede wszystkim, kierunków nieekonomicznych (Płaziak, Rachwał, 2014a; 2014b). Jednym z ważnych oczekiwań w stosunku do efektów tej edukacji, choć nie jedynym, jest zwiększenie poziomu intencji przedsiębiorczych młodego pokolenia, rozumianych jako chęć do założenia i prowadzenia własnego biznesu (por. Byabashaija, Katono, 2011; Fayolle, Gailly, 2015; Galloway, Brown, 2002; Bae et al., 2014). W celu określenia tego poziomu jako jednego z mierników, które powinny być uwzględniane przy formułowaniu celów, treści i metod kształcenia w zakresie przedsiębiorczości, ważne jest rozpoznanie intencji przedsiębiorczych młodzieży, w tym studentów. Badania takie prowadzone są przez wielu badaczy w różnych ośrodkach w Polsce i za granicą (m.in. Kilar, Rachwał, 2014; Kosała, 2014; Kosała, Pichur, 2008; Kuehn, 2008; Kwieciński, Młodzińska-Granek, 2014; Zbierowski, 2014).

W nawiązaniu do tych przesłanek przedmiotem artykułu są wyniki badań intencji przedsiębiorczych studentów kierunków nieekonomicznych celem określenia wpływu wybranych czynników na intencje przedsiębiorcze młodych ludzi. Artykuł opiera się na przeglądzie 
literatury przedmiotu, a także na wynikach ankietyzacji studentów Uniwersytetu Pedagogicznego w Krakowie (Wydziału Geograficzno-Biologicznego - kierunki: geografia, gospodarka przestrzenna oraz turystyka i rekreacja oraz Wydziału Filologicznego - kierunek: architektura informacji). W pierwszej części dokonano przeglądu literatury przedmiotu, a w drugiej przedstawiono wyniki analiz danych pozyskanych za pomocą ankiet w celu weryfikacji postawionych, przedstawionych szczegółowo w dalszej części artykułu, hipotez badawczych.

\section{Intencje przedsiębiorcze w ujęciu teoretyczno-koncepcyjnym}

Jak podkreśla A. Kurczewska (2013), wokół intencji przedsiębiorczych rozpoczęto w ostatniej dekadzie wnikliwe badania, które korzystają w dużej mierze z dorobku nauk behawioralnych (psychologii i socjologii). Wiele z nich opiera się na pochodzącej z połowy lat 80 . $\mathrm{XX}$ w. teorii planowanego zachowania (theory of planned behaviour - TPB) opracowanej przez I. Ajzena (1987; 1991). Zgodnie z tą teorią intencje zachowania zależą od trzech antecedencji: I) tego, jakie mamy do tego zachowania nastawienie, II) postrzeganej kontroli zachowania, czyli wykonalności, oraz III) norm społecznych, które kształtują postrzeganie tego zachowania. Pierwsze dwa czynniki, czyli postawa względem danego zachowania, a raczej rezultatów związanych z tym zachowaniem, oraz postrzeganie norm społecznych względem tego zachowania, odzwierciedlają celowość oraz pożądanie zaistnienia takiego zachowania. Trzeci czynnik natomiast odzwierciedla osobiste postrzeganie możliwości kontrolowania danego zachowania i tożsamy jest z poczuciem własnej skuteczności (Wach, 2015). Teoria planowanego zachowania jest jedną z najpopularniejszych ogólnych koncepcji zachowania. Odwołuje się do niej wielu autorów próbujących wyjaśniać intencje przedsiębiorcze (por. Gelderen et al., 2008; Gird, Bagraim, 2008; Krueger, Carsrud, 1993), które są najczęściej definiowane jako własne przekonanie o zamierzeniu stworzenia przedsięwzięcia gospodarczego i świadomym planowaniu tego procesu w przyszłości (Zbierowski, 2014). Podobnie definiują intencje przedsiębiorcze inni autorzy, np. N. Krueger (1993) jako skłonność oraz posiadanie potencjału do rozpoczęcia własnej działalności gospodarczej w niedalekiej przyszłości. Poszczególni autorzy podkreślają znaczenie różnych czynników w pobudzaniu intencji przedsiębiorczych, np. W. Byabashaija oraz I. Katono (2011), ale także T.J. Bae i in. (2014) podkreślają szczególną rolę czynników sytuacyjnych (takich jak zdolność do zatrudnienia czy zdolność do poświęceń i zobowiązań) oraz cech osobowościowych, na co zwracają szczególną uwagę także M. Koçoğlu i M.U. Hassan (2013) oraz W. Kilar i T. Rachwał (2014). Ci drudzy autorzy podkreślili także, w wyniku wcześniejszych badań ankietowych studentów tego samego uniwersytetu, duży wpływ barier wewnętrznych, do jakich należy negatywna ocena własnej osobowości czy brak predyspozycji do bycia przedsiębiorcą związany m.in. z trudnościami w podejmowaniu decyzji, co wpływa istotnie na obniżenie poziomu intencji przedsiębiorczych studentów. A.S. Gubik i S. Farkas (2015) podkreślają natomiast, że zmieniający się charakter młodego pokolenia studentów prowadzi do nowych oczekiwań związanych ze stylem życia, warunkami pracy i rozwojem kariery zawodowej, co ma istotny wpływ na intencje w zakresie zakładania własnej działalności gospodarczej. Szeroko dyskutowana, przez tych i innych autorów, jest także kwestia wpływu procesu edukacyjnego, w tym na poziomie szkół wyższych, na intencje przedsiębiorcze (Żur, 2014). W jednych z najnowszych badań w tym zakresie, autorstwa A. Fayolle i B. Gailly (2015), wykazano, że pozytywne skutki edukacyjnych programów z przedsiębiorczości zaznaczają się bardziej, gdy początkowe intencje zakładania działalności gospodarczej są słabe lub nie istnieją. 
Stwierdzono wręcz, iż wpływ programów edukacyjnych w zakresie przedsiębiorczości jest ujemnie skorelowany z początkowym poziomem intencji przedsiębiorczych. Z badań tych wynika także, że krótkie, obowiązkowe programy edukacyjne (kursy) wprowadzające w problematykę (do 24 godzin zajęć) nie pozwalają zaobserwować oczekiwanych efektów w perspektywie krótkoterminowej, a jedynie pewien efekt w perspektywie średnioterminowej (6 miesięcy od zakończenia). Oznacza to, że problem analizy wpływu różnorodnych czynników, w tym edukacji dla przedsiębiorczości, na intencje przedsiębiorcze jest bardzo złożony i może być rozpatrywany z wielu punktów widzenia. W literaturze przedmiotu zauważyć można także inne koncepcje zachowań przedsiębiorczych, które mogą być podstawą teoretyczną badań empirycznych. W niniejszej pracy ograniczono się jednak do prezentacji teorii planowanego zachowania jako tej, która została przyjęta w założeniach metodycznych badań.

\section{Założenia metodyczne badań}

Celem badań empirycznych była próba implementacji teorii planowanego zachowania Ajzena $(1987 ; 1991 ; 2011)$ wśród grupy studentów w polskich realiach. Jest to jedna z najczęściej stosowanych koncepcji przy analizowaniu intencji zachowania, zwłaszcza intencji przedsiębiorczych w literaturze anglojęzycznej, choć należy podkreślić, że także w polskiej literaturze przedmiotu badania oparte na tej koncepcji zaczynają się już pojawiać (Jiménez-Moreno, Wach, 2014; Wach, 2015; Rantanen, Pawlak, Toikko, 2015; Pawlak, 2015; Kwieciński, Młodzińska-Granek, 2014).

Warto sprawdzić to teoretyczne ujęcie teorii planowanego zachowania w aspekcie intencji przedsiębiorczych polskich studentów, stąd za ramami teoretycznymi przyjmujemy następujące hipotezy:

H1: Im lepsza jest indywidualna postawa względem prywatnej przedsiębiorczości i przedsiębiorców, tym wyższe są intencje przedsiębiorcze danej jednostki.

H2: Im wyższa jest skłonność jednostki do podejmowania ryzyka, tym wyższe są jej intencje przedsiębiorcze.

H3: Im wyższe są w społeczeństwie subiektywne normy wobec prywatnej przedsiębiorczości, tym wyższe są intencje przedsiębiorcze danej jednostki.

H4: Im wyższe jest poczucie własnej skuteczności przedsiębiorczej, tym wyższe są intencje przedsiębiorcze jednostki.

Dodatkowo obserwacja życia gospodarczego, funkcjonowania przedsiębiorstw rodzinnych oraz rozmowy ze studentami, których rodzice prowadzą rodzinne biznesy, skłaniają do przypuszczenia, że środowisko i doświadczenie biznesu rodzinnego wpływają pozytywnie na intencje przedsiębiorcze, co pozwala przyjąć kolejną hipotezę:

H5: Studenci pochodzący z rodzin z tradycjami biznesu rodzinnego wyrażają większe intencje przedsiębiorcze niż ci, którzy nie mają takich doświadczeń.

Do empirycznego weryfikowania postawionych hipotez wykorzystano odpowiednie metody statystyczne (statystyki opisowe, korelacja liniowa Pearsona, analiza ANOVA).

Jako główne narzędzie badawcze zastosowano ankietyzację wśród grupy studentów Uniwersytetu Pedagogicznego w Krakowie. Kwestionariusz ankiety został podzielony na 14 części tematycznych, z których pierwsze 4 dotyczyły zmiennych zależnych (postawa przedsiębiorcza, postawa względem ryzyka, subiektywne normy, postrzegana kontrola zachowania), 1 zmiennej niezależnej (intencje przedsiębiorcze), natomiast ostatnia część zawierała podstawowe 
charakterystyki danego respondenta, które posłużyły jako zmienne kontrolne. Pozostałe części ankiety dotyczyły innych aspektów związanych z konceptualizacją intencji przedsiębiorczych (m.in. przedsiębiorczych zdolności, edukacji dla przedsiębiorczości, postrzegania wsparcia i barier dla przedsiębiorczości, poczucia umiejscowienia kontroli, proaktywności i proaktywnej osobowości, innowacyjności i innowacyjnej osobowości, oczekiwanych rezultatów przedsiębiorczości). Części dotyczące zmiennych zależnych i zmiennej niezależnej zawierały od 4 do 7 pytań ocenianych w 7-stopniowej skali Likerta, które następnie ustandaryzowano i nadano im postać zmiennych quasi-ciągłych przez zbudowanie indeksów zagregowanych.

Ankietyzację przeprowadzono w czerwcu 2015 r. na Uniwersytecie Pedagogicznym w Krakowie, a prace badawcze przeprowadzono $\mathrm{w}$ ramach projektu badania intencji przedsiębiorczych studentów (EIQ 2015) prowadzonego przez Centrum Przedsiębiorczości Strategicznej i Międzynarodowej Uniwersytetu Ekonomicznego w Krakowie.

W ankietyzacji z ramienia Uniwersytetu Pedagogicznego w Krakowie wzięło udział 66 studentów, co stanowi próbę badawczą, na podstawie której dokonano dalszej analizy statystycznej i weryfikacji hipotez. Kobiety stanowiły $85 \%$, a mężczyźni zaledwie $15 \%$ próby badawczej. Ze względu na wiek próba badawcza była zdominowana przez osoby w wieku 22-23 lata (40\%) oraz w wieku $20-21$ lat (35,4\%), przy czym 18,5\% studentów było młodszych, a zaledwie $6,5 \%$ - starszych.

\section{Wyniki badań}

W celu weryfikacji hipotez H1-H4, które zakładały proporcjonalną zależność pomiędzy badanymi zmiennymi do obliczeń zastosowano korelację liniową Pearsona (tab. 1). Wyniki statystyczne pozytywnie weryfikują wszystkie możliwe korelacje w ujęciu zmiennych zgodnie z modelem Ajzena, nasilenie współzależności badanych cech jest jednak różne ${ }^{1}$. Wszystkie wykryte korelacje są dodatnie oraz wszystkie są istotne statystycznie $(p<0,01)$. Tylko w jednym wypadku wystąpiła bardzo silna korelacja - chodzi o współzależność zmiennych „intencje przedsiębiorcze” oraz „postawa względem przedsiębiorczości”. Silna korelacja wystąpiła pomiędzy zmienną „intencje przedsiębiorcze” a zmiennymi „subiektywne normy” oraz „poczucie własnej skuteczności przedsiębiorczej”. W przypadku zmiennej „postawa względem ryzyka" zanotowano średnią korelację. Wyniki statystyczne potwierdzają zatem pierwsze cztery hipotezy badawcze.

Co więcej, analogiczne obliczenia wewnątrz modelu potwierdzają dalsze trzy silne korelacje (tab. 1). Postawa jednostki względem przedsiębiorczości jest silnie skorelowana z postawą jednostki względem ryzyka. Im wyższa skłonność jednostki do podejmowania ryzyka, tym lepsza jest indywidualna postawa względem prywatnej przedsiębiorczości i przedsiębiorców. Analogicznie, im wyższa samoocena własnej skuteczności, tym lepsza indywidualna postawa względem przedsiębiorczości. Im przedsiębiorczość cieszy się większą estymą wśród społeczeństwa jako całości, tym lepsza jest indywidualna ocena przedsiębiorczości prywatnej.

\footnotetext{
${ }^{1}$ Za Zielińskim (1999: 134) przyjmujemy następujące nasilenie współzależności badanych cech:

$|0,0-0,2|$ brak korelacji,

$|0,2-0,3|$ słaba korelacja,

$|0,3-0,5|$ średnia korelacja,

$|0,5-0,7|$ silna korelacja,

$|0,7-1,0|$ bardzo silna korelacja.
} 
Tab. 1. Korelacja liniowa pomiędzy zmiennymi modelu I. Ajzena

\begin{tabular}{|l|c|c|c|c|c|}
\cline { 2 - 6 } \multicolumn{1}{c|}{} & IP & PWP & PWR & SN & PWSP \\
\hline IP & $1,0^{* * *}$ & & & & \\
\hline PWP & $0,8^{* * *}$ & $1,0^{* * *}$ & & & \\
\hline PWR & $0,4^{* * *}$ & $0,5^{* * *}$ & $1,0^{* * *}$ & & \\
\hline SN & $0,6^{* * *}$ & $0,6^{* * *}$ & $0,4^{* * *}$ & $1,0^{* * *}$ & \\
\hline PWSP & $0,5^{* * *}$ & $0,5^{* * *}$ & $0,4^{* * *}$ & $0,3^{*}$ & $1,0^{* * *}$ \\
\hline
\end{tabular}

${ }^{* * *} p<0,000 * p=0,01$

Legenda: IP - intencje przedsiębiorcze, PWP - postawa względem przedsiębiorczości, PWR - postawa względem ryzyka, SN - subiektywne normy, PWSP - poczucie własnej skuteczności przedsiębiorczej

Źródło: obliczenia własne przy użyciu oprogramowania Statistica PL

Aby bliżej określić różnice dla zmiennej grupującej „biznes rodzinny”, postanowiono zastosować jednoczynnikową analizę wariancji ANOVA. Dokonano oceny zgodności rozkładu normalnego przy użyciu testu Shapiro-Wilka, którego wyniki nie dały podstaw do odrzucenia założenia normalności rozkładu. Założenie równości wariancji zostało potwierdzone przy użyciu testu Levene’a oraz testu Browna-Forsythe’a, co umożliwiło przeprowadzenie analizy wariancji (tab. 2). Na podstawie wartości prawdopodobieństwa testowego $p$ możemy odrzucić hipotezę zerową zakładającą brak zróżnicowania wartości przeciętnych, co oznacza, że ze względu na zmienną grupującą „biznes rodzinny” zróżnicowanie takie występuje, a wyniki te potwierdzają zakładaną hipotezę H5. Średnia ocena intencji przedsiębiorczych studentów mających doświadczenie biznesu rodzinnego wynosiła 4,4 (20 obserwacji) wobec $3,5 \mathrm{w}$ wypadku pozostałych studentów (46 obserwacji) przy zastosowaniu 7-stopniowej skali Likerta (ryc. 1).

Tab. 2. Wyniki analizy wariancji dla zmiennej grupującej „biznes rodzinny”

\begin{tabular}{|l|c|c|c|c|c|c|c|c|}
\hline \multicolumn{1}{|c|}{ Zmienne } & $\begin{array}{c}\text { SS } \\
\text { efekt }\end{array}$ & $\begin{array}{c}\text { df } \\
\text { efekt }\end{array}$ & $\begin{array}{c}\text { MS } \\
\text { efekt }\end{array}$ & $\begin{array}{c}\text { SS } \\
\text { błąd }\end{array}$ & $\begin{array}{c}\text { df } \\
\text { błąd }\end{array}$ & $\begin{array}{c}\text { MS } \\
\text { błąd }\end{array}$ & F & $p$ \\
\hline $\begin{array}{l}\text { Intencje } \\
\text { przedsiębiorcze }\end{array}$ & 11,24809 & 1 & 11,24809 & 101,7850 & 64 & 1,590391 & 7,072535 & 0,009879 \\
\hline $\begin{array}{l}\text { Postawa } \\
\text { przedsiębiorcza }\end{array}$ & 12,53921 & 1 & 12,53921 & 85,4116 & 64 & 1,334557 & 9,395788 & 0,003183 \\
\hline $\begin{array}{l}\text { Postawa wobec } \\
\text { ryzyka }\end{array}$ & 0,35796 & 1 & 0,35796 & 70,2098 & 64 & 1,097028 & 0,326298 & 0,569848 \\
\hline $\begin{array}{l}\text { Subiektywne } \\
\text { normy }\end{array}$ & 5,22636 & 1 & 5,22636 & 79,6558 & 64 & 1,244622 & 4,199153 & 0,044548 \\
\hline $\begin{array}{l}\text { Postrzegana } \\
\text { skuteczność }\end{array}$ & 0,02711 & 1 & 0,02711 & 53,0670 & 64 & 0,829171 & 0,032694 & 0,857085 \\
\hline
\end{tabular}

Źródło: opracowanie własne na podstawie przeprowadzonej ankietyzacji ( $n=66$, czerwiec 2015) 
Ryc. 1. Wykres interakcji między intencjami przedsiębiorczymi a doświadczeniem biznesu rodzinnego wśród ankietowanych studentów

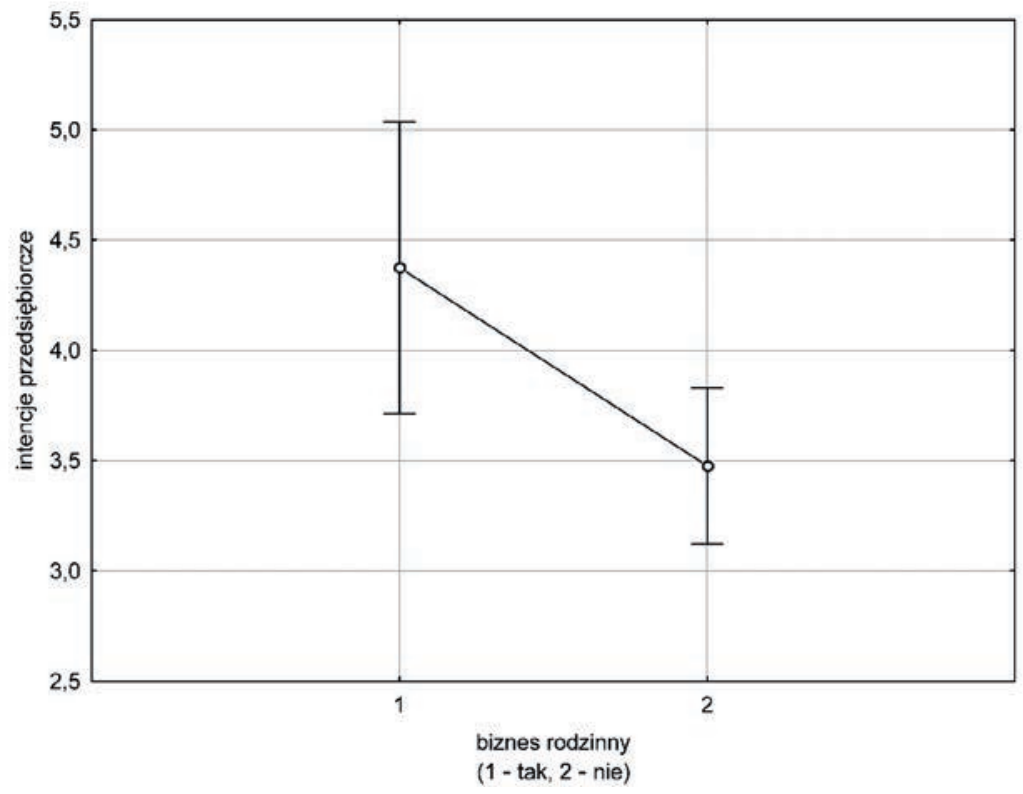

Źródło: opracowanie własne na podstawie przeprowadzonej ankietyzacji ( $n=66$, czerwiec 2015)

\section{Podsumowanie}

$\mathrm{Na}$ intencje przedsiębiorcze młodych ludzi wpływa wiele różnorodnych czynników, wśród których istotne znaczenie, zgodnie $\mathrm{z}$ teorią planowanego zachowania, mają czynniki związane z postawą wobec prywatnej przedsiębiorczości, skłonnością do podejmowania ryzyka, subiektywne normy wobec prywatnej przedsiębiorczości w społeczeństwie oraz poczucia własnej skuteczności przedsiębiorczej, a także doświadczenia biznesu rodzinnego. Wyniki statystyczne zaprezentowane w artykule pozwalają na przyjęcie wszystkich zakładanych hipotez, wskazujących na związki między tymi czynnikami a intencjami przedsiębiorczymi studentów:

1. Wraz z pozytywnym wzrostem indywidualnej postawy względem prywatnej przedsiębiorczości i przedsiębiorców, zwiększają się intencje przedsiębiorcze badanych studentów, a zmienne te są bardzo silnie skorelowane $(\mathrm{r}=0,8, p=0,0000)$.

2. Średnia korelacja występuje pomiędzy skłonnością badanych studentów do podejmowania ryzyka a ich intencjami przedsiębiorczymi.

3. Prawidłowość o silnym nasileniu wystąpiła dla subiektywnych norm społecznych $(r=0,6$, $p=0,000)$. Im subiektywne normy wobec prywatnej przedsiębiorczości są w społeczeństwie wyższe, tym wyższe są intencje przedsiębiorcze danej jednostki.

4. Wraz ze wzrostem poczucia własnej skuteczności przedsiębiorczej wzrastają intencje przedsiębiorcze badanych studentów, a nasilenie współzależności jest silne $(r=0,5, p=0,000)$.

5. Doświadczenia przedsiębiorczości rodzinnej przyczynia się „większych” intencji przedsiębiorczych wśród badanych studentów. 
Jak każde badania empiryczne oparte na percepcji, także i te omówione w artykule mają swoje ograniczenia. Po pierwsze, próba badawcza $(n=66)$ była dość ograniczona - warto takimi badaniami objąć całą populację danego uniwersytetu. Po drugie, wnioskowanie na podstawie percepcji, choć w pełni akceptowalne przez psychologów i mające wiele potwierdzeń w rzeczywistości, nadal nie pozwala na absolutyzowanie wniosków w badaniach nad przedsiębiorczością.

Zebrany materiał empiryczny - a przede wszystkim wyniki badań - wskazuje na możliwości rozszerzenia badań o nowe wątki badawcze, takie jak motywy pozytywne i negatywne w podejmowaniu decyzji o uruchamianiu działalności gospodarczej. Warto także przeprowadzić badania porównawcze studentów różnych kierunków, w tym ekonomicznych i pozaekonomicznych, oraz uwzględnić problematykę wpływu zajęć z zakresu przedsiębiorczości na badane zjawisko.

Literatura

References

Ajzen, I. (1987). Attitudes, traits, and actions: Dispositional prediction of behaviour in social psychology. Advances in Experimental Social Psychology, 20, 1-63.

Ajzen, I. (1991). The theory of planned behavior. Organizational Behaviour and Human Decision Processes, 50, 179-211.

Ajzen, I. (2011). The theory of planned behaviour: Reactions and reflections. Psychology \& Health, 26(9), 1113-1127. Pozyskano z: http://dx.doi.org/10.1080/08870446.2011.613995

Bae, T.J., Qian, S., Miao, Ch., Fiet, J.O. (2014). The Relationship Between Entrepreneurship Education and Entrepreneurial Intentions: A Meta-Analytic Review. Entrepreneurship Theory and Practice, $38(2), 217-254$.

Borowiec, M., Rachwał, T. (2011). Kształtowanie postaw przedsiębiorczych na lekcjach geografii wyzwaniem edukacyjnym w procesach globalizacji. Przedsiębiorczość - Edukacja, 7, 321-332.

Byabashaija, W., Katono, I. (2011). The Impact of College Entrepreneurial Education on Entrepreneurial Attitudes and Intention to Start a Business in Uganda, Journal of Developmental Entrepreneurship, 16(1), 127-144.

Daszkiewicz, N. (2013), Education as a Stimulating Factor for Entrepreneurship Development. Horyzonty Wychowania, 13(26), 165-177.

Fayolle, A., Gailly, B. (2015), The Impact of Entrepreneurship Education on Entrepreneurial Attitudes and Intention: Hysteresis and Persistence. Journal of Small Business Management, 53: 75-93. DOI: $10.1111 /$ jsbm. 12065

Galloway, L., Brown, W. (2002). Entrepreneurship education at university: a driver in the creation of high growth firms? Education + Training, 44(8/9), 398-405.

Gaweł, A. (2011). Kształcenie uniwersyteckie jako czynnik wpływający na przedsiębiorczość. Zeszyty Naukowe Uniwersytetu Ekonomicznego w Poznaniu, 215, 71-87.

Gelderen, M. van., Brand, M., Praag, M. van, Bodewes, W., Poutsma, E., Gils, A. van. 2008. Explaining entrepreneurial intentions by means of the theory of planned behaviour. Career Development International, 13(6), 538-559.

Gird, A., Bagraim, J.J. 2008. The theory of planned behaviour as predictor of entrepreneurial intent amongst final-year university students. South African Journal of Psychology, 38(4), 711-724.

Gubik, A.S. (2015). Understanding Career Aspirations of Hungarian Students (chapter 9). In: A.S. Gubik, K. Wach (Eds.). Institutional Aspects of Entrepreneurship. Miskolc: University of Miskolc, 131-150.

Gubik, A.S., Farkas, S. (2015). Impact of Career Motives Changes on Entrepreneurial Intentions among Hungarian Students (chapter 10). In: A.S. Gubik, K. Wach (Eds.). Institutional Aspects of Entrepreneurship. Miskolc: University of Miskolc, 151-164. 
Jiménez-Moreno, J.J., Wach, K. (2014). The Entrepreneurial Profile of Students Participating in the Academic Entrepreneurship Course: Pilot Study Results. Horyzonty Wychowania, 13(26), 121-143.

Kilar, W., Rachwał, T. (2014). Postrzeganie zakładania własnej działalności gospodarczej jako przejaw postawy przedsiębiorczej przez studentów kierunków nieekonomicznych. Horyzonty Wychowania, 13(28), 111-130.

Koçoğlu, M., Hassan, M.U. (2013): Assessing Entrepreneurial Intentions of University Students: A Comparative Study of Two Different Cultures: Turkey and Pakistani. European Journal of Business and Management, 5(13), 243-252.

Kokocińska H. Nowak (red.), Edukacja w zakresie przedsiębiorczości: doświadczenia Polski i Hiszpanii. Warszawa: Difin.

Kosała, M. (2014). Badanie postaw przedsiębiorczych wśród młodzieży jako fundament kształtowania postawy odpowiadającej wyzwaniom współczesnego świata. Horyzonty Wychowania, 13(28), 317-340.

Kosała, M., Pichur, A. (2008). Analiza działań przedsiębiorczych i postrzeganie prowadzenia działalności gospodarczej wśród młodego pokolenia - wybrane aspekty. Przedsiębiorczość - Edukacja, $4,347-354$.

Krueger, N. (1993). Impact of prior entrepreneurial exposure on perceptions of new venture feasibility and desirability. Entrepreneurship Theory and Practice, 18(1), 5-21.

Krueger, N., Carsrud, A. (1993). Entrepreneurial intentions: Applying the theory of planned behaviour. Entrepreneurship \& Regional Development, 5(4), 315-330.

Kuehn, K.W. (2008). Entrepreneurial Intensions Research: Implications for Entrepreneurship Education. Journal of Entrepreneurship Education, 11, 87-98.

Kurczewska, A. (2013). Przedsiębiorczość jako proces współoddziaływania sposobności i intencji przedsiębiorczych. Warszawa: PWE.

Kwiatkowska, H. (2008). Pedeutologia. Warszawa: Wydawnictwa Akademickie i Profesjonalne.

Kwieciński, L., Młodzińska-Granek, A. (2014). Academic Entrepreneurship in the Humanities and Social Sciences: Research Conducted among Students of Wroclaw University. Horyzonty Wychowania, 13(26), 33-50.

Marona, B., Głuszak M. (2014). The Ties that Bind? Real Estate Education in Europe and Regulatory Framework in Poland. The New Educational Review, 35(1), 187-201.

Najda-Janoszka, M., Wach, K. (2008). Lifelong Learning in the Field of Tourism in the European Union taking Poland into Special Consideration. In: M. Bednarczyk (Ed.), Entrepreneurship in Tourism and Sport Business. Kraków: Fundacja dla Uniwersytetu Jagiellońskiego, 45-58.

Pawlak, A. (2015). Wpływ rodziców-przedsiębiorców na występowanie intencji przedsiębiorczych u młodzieży szkół średnich w Polsce. Przedsiębiorczość i Zarządzanie, XVI(7[III]), 71-82.

Pietrzykowski, M. (2011). Entrepreneurship in Higher Education - the case of Poland. In: M. Dabić, M. PIetrzykowski (Eds.), Fostering Education in Entrepreneurship. Poznań: Wydawnictwo Naukowe Bogucki, 113-128.

Piróg, D. (2015). Kompetencje z zakresu przedsiębiorczości: rozważania teoretyczne i ich ilustracje w obszarze szkolnictwa wyższego. Przedsiębiorczość - Edukacja, 11, 364-376.

Płaziak, M., Rachwał, T. (2014a). Entrepreneurship Courses in Spatial Management Studies in Polish Universities. Procedia - Social and Behavioral Sciences, 110, 710-718. Pozyskano z: http://dx.doi. org/10.1016/j.sbspro.2013.12.915

Płaziak, M., Rachwał, T. (2014b). Kształcenie w zakresie przedsiębiorczości w polskich uniwersytetach na studiach nieekonomicznych (na przykładzie kierunku geografia). Horyzonty Wychowania, 13(26), 249-266.

Rachwał, T. (2010). Entrepreneurship Education as a Growth Stimulus for Family Firms (chapter 9). In: A. Surdej, K. Wach (Eds), Exploring the Dynamics of Entrepreneurship. Torun: Marszałek Publishing House, 139-156. 
Rachwał, T., Kurek, S., Boguś, M. (2016). Entrepreneurship Education at Secondary Level in Transition Economies: A Case of Poland. Entrepreneurial Business and Economics Review, 4(1), 61-81. DOI: http://dx.doi.org/10.15678/EBER.2016.040105

Rantanen, T., Pawlak A., Toikko, T. (2015). The Significance of Social Welfare Attitudes in Young People's Entrepreneurial Intentions. Entrepreneurial Business and Economics Review, 3(1). DOI: http://dx.doi.org/10.15678/EBER.2015.030104

Sułkowski, Ł. (2016). Kultura akademicka - koniec utopii?. Łódź: Wydawnictwo Społecznej Akademii Nauk w Łodzi.

Tomski, P. (2014). Rodzinna osnowa intencji przedsiębiorczych. Przedsiębiorczość i Zarządzanie, XV(7[III]), 319-334.

Urbaniec, M. (2014). Współczesne wyzwania edukacji na rzecz przedsiębiorczości w szkolnictwie wyższym. Horyzonty Wychowania, 13(26), 209-230.

Wach, K. (2007). Kształtowanie postaw przedsiębiorczych w programach nauczania: Stan obecny i proponowane kierunki zmian. W: P. Wachowiak, M. Dąbrowski, B. Majewski (red.), Kształtowanie postaw przedsiębiorczych a edukacja ekonomiczna. Warszawa: Fundacja Promocji i Akredytacji Kierunków Ekonomicznych, 120-127.

Wach, K. (2013). Edukacja na rzecz przedsiębiorczości wobec współczesnych wyzwań cywilizacyjno-gospodarczych. Przedsiębiorczość - Edukacja, 9, 246-257.

Wach, K. (2014a). Edukacja dla przedsiębiorczości: pomiędzy przedsiębiorczą pedagogiką a edukacją ekonomiczną i biznesową. Horyzonty Wychowania, 13(28), 11-31.

Wach, K. (2014b). Europeanisation od Entrepreneurship Education in Europe - Looking Back and Looking Forward. Horyzonty Wychowania, 13(26), 11-32.

Wach, K. (2015). Środowisko biznesu rodzinnego jako stymulanta intencji przedsiębiorczych młodzieży akademickiej. Przedsiębiorczość i Zarządzanie, XVI(7[III]), 25-40.

Zbierowski, P. (2014). Determinanty intencji przedsiębiorczej studentów - wyniki badań. Horyzonty Wychowania, 13(26), 51-63.

Zieliński, T. (1999). Jak pokochać statystykę. Kraków: Wydawnictwo StatSoft.

Zioło Z. (2013). Miejsce przedsiębiorczości w edukacji. Przedsiębiorczość - Edukacja, 8, 10-23.

Żur, A. (2014). Exploring the Role of Inspiration in Entrepreneurship Education. Horyzonty Wychowania, 13(26), 179-194.

Tomasz Rachwal, dr, Uniwersytet Pedagogiczny im. Komisji Edukacji Narodowej w Krakowie, Instytut Geografii, Zakład Przedsiębiorczości i Gospodarki Przestrzennej. Kierownik Zakładu Przedsiębiorczości i Gospodarki Przestrzennej Instytutu Geografii Uniwersytetu Pedagogicznego w Krakowie. Autor lub współautor podręczników szkolnych i akademickich z zakresu geografii ekonomicznej i przedsiębiorczości. Jego zainteresowania badawcze skupiają się przede wszystkim na problematyce przemian struktur przestrzennych przemysłu, funkcjonowania różnych branż działalności gospodarczej, restrukturyzacji przedsiębiorstw oraz roli przedsiębiorczości w rozwoju układów przestrzennych, a także edukacji w zakresie przedsiębiorczości.

Tomasz Rachwal, PhD, Pedagogical University of Cracow, Institute of Geography, Department of Entrepreneurship and Spatial Management. Head of the Department of Entrepreneurship and Spatial Management of the Institute of Geography of the Pedagogical University of Cracow. The author or co-author of school and academic textbooks on economic geography and entrepreneurship. His research interests focus primarily on the issue of change of spatial structures of industry, the functioning of various branches of industrial activity, corporate restructuring and the role of entrepreneurship in the development of spatial systems as well as entrepreneurship education.

\section{Adres/Address:}

Uniwersytet Pedagogiczny im. Komisji Edukacji Narodowej w Krakowie

Instytut Geografii

Zakład Przedsiębiorczości i Gospodarki Przestrzennej 
ul. Podchorążych 2

30-084 Kraków, Polska

e-mail: T.Rachwal@up.krakow.pl

Krzysztof Wach, dr hab., prof. UEK, Uniwersytet Ekonomiczny w Krakowie, Wydział Ekonomii i Stosunków Międzynarodowych, Katedra Handlu Zagranicznego, Kierownik Centrum Przedsiębiorczości Strategicznej i Międzynarodowej. Doktor habilitowany nauk ekonomicznych w zakresie ekonomii, doktor nauk ekonomicznych w zakresie nauk o zarządzaniu, specjalista z zakresu przedsiębiorczości międzynarodowej, autor kilkunastu książek, ponad 150 publikacji naukowych, redaktor naczelny kwartalnika naukowego „Entrepreneurial Business and Economics Review” (EBER), członek komitetów redakcyjnych kilku czasopism naukowych. W latach 2012-2014 pełnił funkcję krajowego eksperta OECD oraz eksperta Komisji Europejskiej ds. przedsiębiorczości, jest uczestnikiem międzynarodowych projektów edukacyjnych i badawczych, odbył gościnne wykłady m.in. w USA, Wielkiej Brytanii, Hiszpanii, Austrii, Chorwacji, a także na Słowacji i Ukrainie.

Krzysztof Wach, PhD., prof. UEK, Cracow University of Economics, Faculty of Economics and International Relations, Department of Foreign Trade (Poland), head of the Centre for Strategic and International Entrepreneurship. Professor extraordinarius (prof. UEK), Habilitated doctor in economics (DEcon), $\mathrm{PhD}$ in management, specialist in international entrepreneurship, author of several books and over 150 scientific articles, editor-in-chief of the scientific quarterly 'Entrepreneurial Business and Economics Review', member of editorial boards of several scientific journals; in the years 2012-2014 an OECD and the European Commission national expert for entrepreneurship, participant of various international education and research projects, visiting professor in various universities in the USA, the UK, Spain, Austria, Croatia, Slovakia and Ukraine.

\section{Adres/Address:}

Uniwersytet Ekonomiczny w Krakowie

Katedra Przedsiębiorczości i Innowacji

ul. Rakowicka 27

31-510 Kraków, Polska

e-mail: wachk@uek.krakow.pl

Artykuł powstał w ramach projektu badawczego nr 054/WE-KPI/02/2015/S/5054 pt. „Przedsiębiorczość inkluzywna: współczesne wyzwania i perspektywy rozwoju” sfinansowanego ze środków przyznanych Wydziałowi Ekonomii i Stosunków Międzynarodowych Uniwersytetu Ekonomicznego w Krakowie, w ramach dotacji na utrzymanie potencjału badawczego. 